Jurnal Evaluasi Pendidikan, Vol. 2, No. 1, Maret 2011, 42-53

http://doi.org/10.21009/JEP

\title{
PROGRAM EVALUATION ON TRAINING FOR ECHELON III IN MINISTRY OF RELIGIOUS AFFAIRS OF THE REPUBLIC OF INDONESIA
}

\author{
Syaukani \\ Fakultas Tarbiyah IAIN Sumatera Utara \\ JI. IAIN No.1 Medan, Sumatera Utara \\ syaukani@gmail.com \\ DOI: doi.org/10.21009/JEP.021.04
}

\begin{abstract}
This is an evaluation study on the training program for the echelon III leader at the Ministry of Religious Affairs. This study utilizes the four levels of Kirkpatrick's evaluation modelreaction, learning, behavior, and results. There are 30 respondents in this study; All of them are the echelon III leaders at the Ministry of Religious Affairs all over Indonesia. The finding of the study shows that the $23^{\text {rd }}$ training program conducted by the center for education and training of the Ministry of Religious Affairs can be categorized well performed, since $85 \%$ of the projected program can be utilized, the substances of the training can be understood and applied at the participants' work environment. However, this study also finds some parts of the training program that ought to be reformed in order to get a better result or outcomes in the future training program. The data informs us that the use of the outsider tutors is still important in order to get a broader knowledge for those who participate in the training and the facilities to support the training should be improved.
\end{abstract}

Keywords: Kirkpatrick's model of evaluation, the echelon III training program, training program effectivity 


\title{
EVALUASI PROGRAM PENDIDIKAN DAN PELATIHAN PIMPINAN ESELON III DI LINGKUNGAN KEMENTRIAN AGAMA RI
}

\author{
Syaukani \\ Fakultas Tarbiyah IAIN Sumatera Utara \\ JI. IAIN No.1 Medan, Sumatera Utara \\ syaukani@gmail.com
}

\begin{abstract}
Abstrak
Penelitian ini merupakan penelitian evaluasi yang difokuskan pada program pendidikan dan pelatihan pejabat eselon III di lingkungan Kementerian Agama RI. Penelitian ini menggunakan model evaluasi Kirkpatrick yang terdiri dari evaluasi: reaksi, pembelajaran, perilaku, dan hasil/dampak. Penelitian menggali informasi dari 30 responden sebagai pejabat eselon III di Kementerian Agama seluruh Indonesia pada pendidikan dan pelatihan angkatan ke 23 tahun 2008. Hasil penelitian menunjukkan bahwa baru $85 \%$ program pelatihan yang dapat dikatakan efektif. Ada beberapa bagian pelatihan yang perlu diperbaiki atau di reformasi agar pencapaian target pelatihan dapat lebih baik dan efektif.
\end{abstract}

Kata kunci: model Evaluasi Kirkpatrick, pendidikan dan pelatihan pejabat eselon III, efektivitas program pelatihan

\section{PENDAHULUAN}

Peraturan Pemerintah Nomor 101 Pasal 2 tahun 2000 tentang pendidikan dan pelatihan bagi pimpinan (diklatpim) tingkat III bertujuan: (a) meningkatkan pengetahuan, keahlian, keterampilan, dan sikap untuk dapat melaksanakan tugas jabatan struktural eselon III secara professsional, (b) menciptakan aparatur yang mampu berperan sebagai pembaharu dan perekat persatuan dan kesatuan bangsa, (c) memantapkan sikap dan semangat pengabdian yang berorientasi pada pelayanan, pengayoman, dan pemberdayaan masyarakat, dan (d) menciptakan kesamaan visi dan dinamika pola pikir dalam melaksanakan tugas pemerintahan umum dan pembangunan demi terwujudnya pemerintahan yang baik.

Tingkat ketercapaian tujuan program diklatpim eselon III belum banyak diketahui atau belum terdapat adanya laporan khusus tentang efektivitas program. Efektivitas program ini diketahui dengan cara melaksanakan evaluasi terhadap keseluruhan aspek internal maupun eksternal program. Evaluasi diklat dapat membantu pelaksana diklat dalam menentukan bagaimana melaksanakan pendidikan dan pelatihan dengan efektif. Menurut Ayers (2007: 1) ada empat hal yang perlu dicermati, yakni: 1) planning: menentukan domain (topik-topik, keseluruhan isi) dari pendidikan dan pelatihan, tujuan utamanya, dan objektifnya secara detail, 2) programming: menentukan prosedur pelaksanaan pendidikan 
dan pelatihan, widyaiswara, fasilitas, keuangan, dan sumber-sumber lain yang diperlukan, 3) pelaksanaan pendidikan dan pelatihan: menetapkan aktivitas yang menjamin terlaksananya pendidikan dan pelatihan, dan 4) merubah pendidikan dan pelatihan: tentukan kapan dan mengapa untuk dilanjutkan, dievaluasi, diubah, atau diakhiri aktivitas pendidikan dan pelatihan tersebut.

Penelitian ini bertujuan untuk mengetahui: (1) reaksi (reaction) peserta pendidikan dan latihan pimpinan eselon eselon III Kementerian Agama angkatan ke XXIII terhadap keseluruhan pelaksanaan pendidikan dan pelatihan, (2) peningkatan pengetahuan, perubahan perilaku/behavior, dan peningkatan skill peserta, (3) perilaku (behavior) alumni pendidikan dan latihan pimpinan eselon III terhadap kerja pada organisasi dimana mereka bertugas, dan (4) hasil akhir/dampak (result) dari pendidikan dan latihan pimpinan eselon III yang dapat dilihat dari segi profesionalisme mereka sebagai pimpinan unit kerja.

Kegunaan penelitian ini adalah untuk mendeskripsikan program pendidikan dan pelatihan dari aspek reaksi serta learningnya, dalam proses dan metode yang dipakai untuk mentransfer knowledge; menetapkan apakah tujuan program dapat tercapai; dan menetapkan nilai atau keuntungan dari tujuan.

Pada tataran praktis banyak pihak yang dipandang memiliki kepentingan terhadap informasi akademis yang berkenaan dengan evaluasi program pendidikan dan pelatihan pimpinan. Evaluasi program menurut Joint Committee yang dikutip Brinkerhoff (1986: 15) adalah aktivitas investigasi yang sistematis tentang sesuatu yang berharga dan bernilai dari suatu objek. Evaluasi program mengukur sesuatu sampai sejauhmana tujuan yang berharga dan bernilai dapat direalisasikan dengan baik. Menurut Herman dalam Tayibnapis (2000: 6) evaluasi program adalah segala sesuatu yang anda lakukan dengan harapan akan mendatangkan hasil atau manfaat.

Evaluasi program merupakan suatu proses penilaian terhadap suatu program atau kegiatan. Secara eksplisit terlihat bahwa evaluasi mengacu kepada pencapaian tujuan, sedangkan secara implisit evaluasi harus membandingkan apa yang telah dicapai oleh program dengan apa yang seharusnya dicapai sesuai standar yang telah ditentukan.

Penelitian evaluasi model yang dipilih ini dibangun atas empat tingkatan evaluasi (four levels of evaluation). Pada setiap tingkatan evaluasi didasari atau dibangun dari tingkatan sebelumnya. Evaluasi harus selalu dimulai dari level pertama reaksi (reaction), lalu dilanjutkan ke level berikutnya secara bertahap yakni ke level pembelajaran (learning), kemudian level tiga perilaku (behavior), dan level empat yakni hasil (results). Informasi yang diperoleh dari setiap tingkatan merupakan dasar bagi pelaksanaan evaluasi pada tingkatan berikutnya. Jadi setiap level di atasnya merepresentasikan ukuran efektivitas yang lebih tepat tentang training tersebut, tapi pada waktu yang bersamaan mengharuskan kita untuk menganalisanya.

Penjelasan tentang hubungan setiap level tersebut dikemukakan sebagai berikut: 


\section{Evaluasi Reaksi (Reactions)}

Tahap ini diukur dengan cara menyebarkan questionnaire kepada peserta pada saat kegiatan hampir selesai. Tahap ini mencoba menjawab pertanyaan berkenaan dengan persepsi peserta, apakah mereka menyukai program tersebut? Apakah materinya relevan dengan bidang tugas mereka? Jenis evaluasi ini disebut oleh Kirkpatrick (1994: 3) sebagai "smilesheet". Menurutnya, setiap program, minimum harus dievaluasi hingga tahap/level ini untuk menyiapkan perbaikan (improvement) program tersebut. Reaksi peserta memiliki konsekuensi penting bagi tahap berikutnya, yakni tahap pembelajaran (learning level). Reaksi yang negatif sering sekali dapat dikurangi. Birnbrauer (1987: 53) mengatakan evaluasi ini dilaksanakan melalui pengisian pertanyaan dari angket yang diberikan.

Penilaian pada level ini bergerak dari kepuasan peserta kemudian mencoba untuk menilai kemajuan perkembangan skill, pengetahuan, atau sikap peserta. Pengukuran pada level ini dilakukan dengan cara yang beragam dari tes yang formal ke nonformal baik dalam bentuk penilaian tim atau penilaian perseorangan (team assessment and self-assessment).

\section{Evaluasi Perilaku (Behavior)}

Pengukuran pada tahap ini dilakukan dengan cara menyebarkan angket kepada staf peserta pendidikan dan pelatihan dan kepada peserta/alumni pendidikan dan pelatihan serta diperkuat dengan wawancara baik kepada atasan langsung maupun kepada alumni. Pertanyaan tersebut intinya adalah tentang penambahan pengetahuan dan perubahan perilaku terhadap tugas-tugas di kantor.

\section{Evaluasi Hasil (Results)}

Penggalian data dan informasi dalam penelitian ini dilakukan terhadap 100 orang pejabat eselon II pemerintah daerah peserta diklatpim tingkat II angkatan VII yang diselenggarakan oleh Lembaga Administrasi Negara. Dalam penelitian tersebut terungkap bahwa pelatihan dan materi training memiliki hubungan yang erat dengan kompetensi kepemimpinan pada tingkat daerah. Lebih jauh lagi hasil penelitian menunjukkan bahwa setiap peserta dapat mengembangkan berbagai macam kompetensi kepemimpinan mereka. Selanjutnya pada tahun 2005 Litbang Departemen Agama melakukan evaluasi program diklat guru-guru Pendidikan Agama Sekolah Menengah Atas. Dalam laporan hasil evaluasi Diklat terungkap bahwa penyusunan tujuan dan program diklat belum melibatkan pakar dan praktisi pendidikan dan input seleksi peserta tidak ketat. Hal ini dikemukakan karena usia dan pangkat peserta diklat ada yang belum memenuhi kriteria yang telah ditentukan.

Crohn dan Lee dari University of California Los Angeles melakukan penelitian tentang Evaluation of Youth Leadership Academy Pilot Program 
Jurnal Evaluasi Pendidikan, Vol. 2, No. 1, Maret 2011, 42-53

http://doi.org/10.21009/gEP

January 2005 - June 2005. Penelitian ini bertujuan untuk mengetahui tingkat efektivitas program tersebut. Program tersebut adalah program pelatihan keahlian dalam kepemimpinan (leadership skill). Hasil penelitian menunjukkan bahwa program ini cukup efektif karena dapat meningkatkan kemampuan leadership peserta dari sebelumnya.

Seksi kajian mutu pendidikan LPMP DIY telah mengadakan evaluasi dampak diklat tindak lanjut uji kompetensi bagi Guru SMA Propinsi D.I. Yogyakarta. Dari kegiatan ini diperoleh hasil bahwa:

1. Diklat tindak lanjut uji kompetensi guru SMA Propinsi DIY Tahun 2005 berdampak sangat baik terhadap alumni diklat.

2. Komponen dampak diklat terhadap institusi yang masih perlu ditingkatkan adalah peran guru dalam pengembangan sekolah.

3. Diklat tindak lanjut uji kompetensi guru SMA Propinsi DIY Tahun 2005 berdampak sangat baik terhadap diri pribadi alumni diklat.

4. Komponen dampak diklat terhadap pribadi guru yang masih perlu ditingkatkan adalah kemampuan guru dalam kreativitas dan inovasi.

5. Diklat tindak lanjut uji kompetensi Guru SMA Propinsi DIY Tahun 2005 berdampak baik terhadap kegiatan belajar mengajar (KBM) yang dilakukan oleh guru alumni diklat.

6. Komponen dampak diklat terhadap kegiatan belajar mengajar yang masih perlu ditingkatkan adalah kemampuan guru dalam melakukan evaluasi proses pembelajaran, tindak lanjut evaluasi pembelajaran, dan kemampuan guru dalam menggunakan alat bantu dan media pembelajaran.

Studi yang telah dilakukan mengenai efek pelatihan terhadap implementasi program studi kasus pelatihan sanitarian di propinsi Bali tahun 2007 menunjukkan bahwa efektifitas program diklat sangat ditentukan oleh pelaksana program dan seluruh staf pengajar. Selanjutnya peningkatan pengetahuan peserta pelatihan menunjukkan hasil yang signifikan demikian juga dengan pemahaman materi sesudah pelatihan.

Dari hasil penelitian dan survey tersebut disadari bahwa perlu adanya evaluasi yang terus menerus bagi program pelatihan atau diklat untuk mendapatkan hasil sesuai yang diinginkan atau ditargetkan dari program yang dilaksanakan. Penelitian ini merupakan penelitian evaluatif yang difokuskan pada program pendidikan dan pelatihan pejabat eselon III di lingkungan Kementerian agama RI, dengan menggunakan model evaluasi Kircpatrick.

\section{METODE PENELITIAN}

Kajian penelitian ini dilakukan dengan pendekatan riset evaluatif dengan menggunakan model evaluasi yang dikemukan oleh Kircpatrick yakni evaluasi reaksi, pembelajaran, perilaku, dan dampak/hasil.

Penelitian ini dilaksanakan di Pusat Pendidikan dan Pelatihan Pegawai Negeri Sipil Kementerian Agama RI di Ciputat. Waktu pelaksanaan evaluasi dilaksanakan pada bulan Juli sampai Agustus 2008. Kemudian untuk melihat hasil 
dari diklat pimpinan tersebut tiga bulan setelah pelaksanaan diklat penelitian dilanjutkan, yakni pada bulan Desember 2008 di kantor tempat tugas para alumni diklat.

Pengumpulan data dilakukan dengan cara: 1) penyebaran angket kepada pejabat yang mengikuti diklatpim dan angket kepada staf mereka, 2) inventory checklist, 3) wawancara kepada atasan langsung dan alumni pendidikan dan pelatihan pimpinan, dan 4) studi dokumen dan melihat hasil tes peserta pendidikan dan pelatihan pimpinan. Sumber data diperoleh dari: peserta pelatihan, alumnus pendidikan, atasan, dan pelaksana.

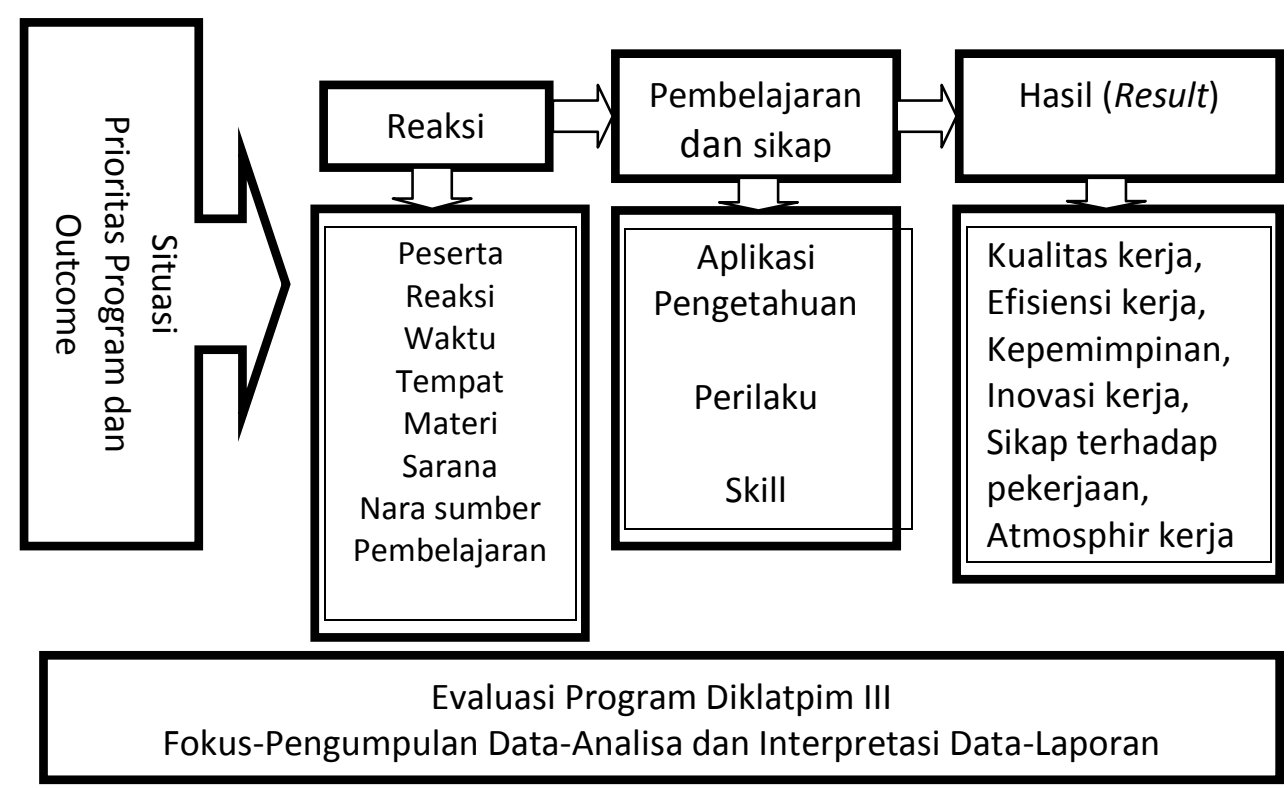

Gambar 1. Desain Penelitian

\section{HASIL PENELITIAN DAN PEMBAHASAN}

Berdasarkan hasil observasi lapangan diketahui bahwa peserta cukup aktif setiap sesi. Namun masih ada sebagian kecil peserta yang kelihatannya mengantuk dalam beberapa sesi penyajian materi. Hasil wawancara menunjukkan bahwa peserta pada umumnya cukup antusias dalam mengikuti diklat pimpinan eselon III. Menurut beliau peserta selalu hadir pada setiap sesi dan mereka aktif dalam mengikuti sesi penyajian materi.

Sebanyak $71,66 \%$ peserta diklat merasa kondisi asrama belum memuaskan, sebanyak $73,33 \%$ peserta diklat merasa kenyamanan kelas belum memadai, dan sebanyak $60 \%$ peserta diklat merasa ketersediaan handout kurang memuaskan. Jadi berdasarkan evaluasi reaksi peserta terhadap lingkungan pelatihan dapat dikatakan efektif karena peserta merasa lingkungan kondusif untuk pelatihan. Namun masalah kenyamanan asrama dan ruangan kelas belum dapat dikatakan baik atau kondusif. Begitu juga dengan ketersediaan handout malah hampir mendekati kriteria tidak kondusif. 
Sebanyak $71,66 \%$ peserta diklat dapat dikatakan kurang aktif dalam mengikuti sesi penyajian materi di kelas, sebanyak $56,3 \%$ responden mengatakan bahwa widyaiswara menarik perhatian mereka dalam penyajian materi, sebanyak $30 \%$ responden mengatakan penyajian widyaiswara sangat menarik, sebanyak $13,3 \%$ responden yang menyatakan bahwa widyaiswara kurang menarik dalam penyajian materi. Namun kalau diberikan skoring terhadap penampilan widyaiswara di kelas memperoleh persentase $75,83 \%$.

Relevansi materi yang disajikan relevan dengan tugas-tugas kantor. Skor yang diperoleh adalah 95 dari skor maksimum 120, dan jika dipersentasikan kedalam skor maksimum maka relevansi materi dengan bidang tugas adalah sebanyak $79,1 \%$ responden menyatakan bahwa relevansi materi yang disajikan relevan dengan tugas-tugas kantor. Sebesar $20 \%$ responden menyatakan bahwa materi pelatihan kurang relevan dengan tugas. Selanjutnya $75,8 \%$ responden mencapai tujuan pembelajaran. Tentang kebermanfaatan ilmu dari diklat, diperoleh $79,1 \%$ dari persentasi skor maksimum. Ada 2 responden yang menyatakan materi diklat kurang bermanfaat. Hal ini diketahui bahwa sebagian materi yang disampaikan sudah mereka ketahui atau pelajari sebelumnya.

Sebanyak 94\% responden mengatakan bahwa kemampuan komunikasi antar staf dan pimpinan atau kemampuan verbal mereka lebih baik. Sebanyak $100 \%$ responden, merasa senang jika saran diberikan oleh stafnya. Terdapat tiga responden yang menyatakan sangat senang jika saran diberikan oleh staf/bawahannya.

Sebanyak 64\% responden mengatakan bahwa mereka merasa mudah dalam pengendalian emosi setelah diklatpim. Selebihnya $29 \%$ responden mengatakan bahwa mereka agak mudah dalam pengendalian emosi di tempat tugas. Ini artinya diklat kurang memberikan perubahan perilaku dalam hal emosi pada alumni diklat terutama pada saat yang genting dan rumit. Dan ada satu responden yang mengatakan diklat pimpinan kurang dapat merubah emosinya.

Mengenai kemampuan team work ternyata cukup baik. Dari penyataan yang disampaikan ternyata mayoritas responden menjawab adanya terjadi perubahan kemampuan kerja tim setelah diklat pimpinan, dimana dinyatakan "kerjasama antara saya dan staf sebagai suatu tim yang utuh lebih baik". Hal ini juga dikatakan oleh atasan mereka dalam wawancara bahwa kerja tim sudah cukup baik.

Sebanyak $82 \%$ responden mengatakan mereka tidak mengalami kesulitan dalam mentransfer pengetahuan kepada staf, dan tiga responden mengatakan bahwa mereka sangat mudah dalam mentransfer ilmu pengetahuan yang diperoleh selama diklat kepada staf. Namun dalam hal kemampuan pemahaman bawahan terhadap arahan pimpinan tampaknya ada kendala. Dari data yang terkumpul tampak bahwa tidak sepenuhnya ilmu yang ditransfer dapat dipahami oleh staf.

Sebanyak $77,7 \%$ responden mengatakan pekerjaan kantor dapat diselesaikan sebelum batas waktu. Ini berarti diklat memberikan dampak positif 
terhadap tugas-tugas kantor. Temuan ini juga didukung beberapa penelitan terdahulu yang menyatakan bahwa training atau pelatihan bagi karyawan akan dapat menghasilkan produktivitas kerja yang lebih baik.

Sebanyak $58 \%$ responden mengatakan bahwa pengetahuan yang mereka dapatkan ketika diklat dapat dipertahankan dengan baik yakni sebanyak $90 \%$. Lima responden mengatakan ilmu yang dapat dipertahankan antara $80 \%$ sampai $75 \%$ saja dan satu responden mengatakan ilmu yang dapat dipertahankan sekitar $70 \%$ saja. Sebagian besar pengetahuan yang diperoleh selama diklat dapat ditransfer kepada bawahan.

Evaluasi perilaku dari peserta pelatihan setelah kembali ke kantor penilaian dapat dikatakan sudah baik kecuali pada beberapa bidang masih perlu perbaikan yakni dalam hal penerapan ilmu kepada staf, mempertahankan ilmu yang didapat dan kemampuan staf dalam memahami arahan pimpinan.

Pada level keempat, level hasil/result ada dua bagian yang ditinjau dari tahapan hasil ini, yakni hasil secara langsung dan tak langsung. Hasil secara langsung yang dilihat adalah kualitas kerja (quality), ketuntasan kerja, efektivitas waktu (time effectiveness), dan efisiensi biaya (budget efficiency). Hasil secara tak langsung yang dilihat adalah kebiasaan kerja, iklim kerja, gaya kerja, perilaku terhadap pekerjaan, dan inisiatif.

Sebanyak 92\% responden menyatakan bahwa dapat menyelesaikan tugas kantor dengan maksimal. Oleh karenanya menurut mereka tugas kantor dapat diselesaikan lebih efektif, yakni pekerjaan dapat diselesaikan tepat waktu. Sebanyak (35\%) responden saja yang mengatakan mereka sedikit mengalami kendala dalam mentransfer pengetahuan kepada staf.

Dalam hal pelaksanaan tugas-tugas dari keputusan yang sudah ditetapkan pimpinan, para staf kelihatannya tidak selalu mengalami kendala, karena sejumlah 5 responden $(29,4 \%)$ mengatakan staf tidak mengalami masalah sama sekali dalam melaksanakan keputusan yang sudah ditetapkan. Sebanyak 10 responden $(58,8 \%)$ mengatakan staf menghadapi sedikit masalah dalam melaksanakan ke-putusan yang dibuat. Dua responden yang mengatakan staf mengalami masalah dalam melaksanakan keputusan yang dibuat.

Dilihat dari segi peningkatan kemampuan kerja (work capability) menunjukkan peningkatan yang cukup baik. 14 responden mengatakan bahwa kemampuan pemecahan masalah dinas bertambah, bahkan 2 responden mengatakan kemampuan pemecahan masalah mereka sangat bertambah setelah mengikuti diklat tersebut. Hanya satu responden mengatakan kemampuan pemecahan masalahnya tetap seperti sebelumnya, dalam artian sudah baik.

Selain itu, kemampuan dalam memberikan feedback kepada atasan juga terjadi penambahan. Semua responden (100\%) mengatakan bahwa mereka memberikan feedback kepada atasan dalam pelaksanaan tugas-tugas kantor. Kemampuan dalam memberikan feedback konstruktif kepada hasil kerja staf juga mengalami penambahan. Tiga belas responden mengatakan kemampuan dalam memberikan feedback konstruktif kepada hasil kerja staf meningkat, bahkan satu 
responden mengatakan sangat meningkat. Hanya dua responden yang mengatakan kemampuan dalam memberikan feedback konstruktif kepada hasil kerja staf kurang bertambah dan satu responden mengatakan tidak bertambah.

Dari aspek kepemimpinan, data menunjukkan bahwa keterbukaan seorang pimpinan terhadap saran yang diberikan staf menunjukkan adanya penambahan. Semua responden mengatakan bahwa mereka terbuka dalam menerima saran dari staf yang berkenaan dengan bidang tugas. Selain dari itu para alumni juga menunjukkan sebagai pemimpin yang baik dalam hal pemberian penghargaan kepada staf yang berprestasi dalam tugas-tugasnya.

Berdasarkan evaluasi terhadap hasil (result) dari diklatpim III dapat disimpulkan bahwa diklatpim telah dapat memberikan dampak atau hasil yang baik terhadap lingkungan kerja dan penampilan kerja (work performance) para alumni diklatpim eselon III angkatan ke XXIII tahun 2008. Namun ada satu bidang yang masih perlu perhatian yakni komunikasi dalam bahasa Inggris yang dituntut sebagai pimpinan eselon III.

Rekruitmen peserta diklat yang tidak berdasarkan tes, tapi berdasarkan kuota dan usulan atasan. Hal ini mengakibatkan peserta pelatihan tidak sama atau lebih kurang sama pengetahuan dan kemampuannya dalam berbagai hal. Selanjutnya hal ini berdampak pada persepsi masing-masing perserta tehadap diklat akan beragam. Pada akhirnya akan mempengaruhi bagi panitia pelaksana dalam menentukan materi yang relevan dengan kemampuan peserta. Untuk itu perlu dipertimbangkan beberapa hal: a) seleksi peserta dilakukan berdasarkan tingkat kelulusan tes yang dibuat secara baku oleh Lembaga Administrasi Negara (LAN), b) mayoritas peserta adalah mereka yang akan menduduki jabatan eselon III, dan c) peserta adalah mereka yang memiliiki bidang tugas yang sama atau paling tidak banyak kesamaan tugasnya.

Untuk mengetahui sejauhmana ketercapaian pembelajaran pada suatu pelatihan atau diklat biasanya dilakukan pretest dan posttest terhadap peserta. Menurut Kirkpatrick harus dilaksanakan tes sebelum (pretest) dan tes sesudah diklat (posttest). Dengan demikian dapat diketahui kemajuan yang dicapai dari aspek pengetahuan, skill dan sikap.

Namun kenyataan di lapangan bahwa tidak dilaksanakan pretest ketika peserta sudah terpilih menjadi peserta diklat pimpinan eselon III. Pihak penyelenggara hanya melaksanakan tes pada akhir program saja, yakni tes dari aspek sikap dan perilaku kepemimpinan serta aspek akademik/penguasaan materi diklat. Panitia penyelenggara seharusnya sudah menyiapkan materi pretest atau kalau belum punya bahan pretest dapat meminta pada Lembaga Administrasi Negara. Oleh karena itu pada penyelenggaraan diklat berikutnya seharusnya pretest dilakukan pada awal setiap diklat apapun tingkatannya. Dengan adanya pretest dan postest maka dapat diketahui sejauhmana keterserapan materi diklat oleh peserta diklat yang pada akhirnya dapat dilihat perbedaan pengetahuan, kemampuan dan skill peserta pendidikan dan pelatihan pimpinan. Dan ini berimplikasi pada peningkatan pelaksanaan diklat kedepan. 
Pada pendidikan dan pelatihan pimpinan kedepan perlu adanya widyaiswara dari tenaga professional seperti dari perguruan tinggi pada mata ajar manajemen bukan hanya mengandalkan tenaga widyaiswara yang ada di Kementerian agama saja.

Peserta diklat yang terdiri dari bidang kerja atau tugas yang heterogen, menimbulkan kekurangefektifan dalam penyajian materi. Oleh karenanya penetapan dan pengelompokan peserta pada pendidikan dan pelatihan pimpinan yang berikut hendaknya terdiri dari pejabat calon pejabat atau eselon III yang memiliki bidang tugas yang sejenis, sehingga penyampaian materi dapat lebih terfokus dan kebermanfaatannya juga lebih tepat.

Bedasarkan data yang terkumpul dan hasil pengamatan transfer pengetahuan sudah cukup baik. Namun, seperti dikemukakan oleh atasan peserta diklat, Direktur Pendidikan Tinggi Islam dan Kepala Pusat Litbang Kementerian agama, tidak dapat mengetahui secara pasti apakah terjadi perubahan sikap ka-rena diklat atau bukan, dan sebenarnya sulit menetapkan kapan perubahan sikap itu terjadi. Untuk mengetahui hal tersebut lembaga kepegawaian perlu melakukan penilaian terhadap kinerja/performance para pejabat yang telah pernah mengikuti pendidikan dan pelatihan pimpinan.

Hasil atau result dalam bentuk unjuk kerja (work performance) atau sumbangsih pada unit kerja merupakan tolok ukur bagi keberhasilan penyelenggaraan program diklat pimpinan eselon III angkatan ke XXIII ini. Hal yang perlu diperhatikan dalam pelaksanaan diklat pimpinan eselon III kedepan dan untuk mendapatkan hasil lebih baik, maka proses pembelajaran perlu disesuaikan de-ngan kemampuan peserta, dalam artian peserta memiliki keahlian dan bidang tugas yang sama, bukan dari mereka yang bekerja pada bidang yang jauh berbeda dengan peserta pelatihan lainnya.

\section{SIMPULAN}

Pada tahapan reaksi (reaction), peserta merasa antusias, penuh perhatian untuk mengikuti diklat dan merasa rugi serta kesal jika meninggalkan sesi pelatihan. Persentasi skor maksimum rata-rata adalah $88,3 \%$ dengan skor ratarata adalah 106. Terkait dengan masalah kenyamanan asrama dan ruangan kelas belum bisa dikatakan baik atau kondusif karena rata-rata skor yang diberikan untuk bidang ini adalah 88 dengan persentasi skor maksimumnya 73,3\%. Namun ketersediaan handout masih dianggap kurang kondusif karena skor yang diperoleh sebanyak 72 dan persentasi skor maksimumnya adalah $60 \%$. Menurut Kirkpatrick kondisi seperti ini tentu berdampak pada keberhasilan diklat. Reaksi keaktifan peserta terhadap sesi pelatihan dapat dikatakan aktif walaupun persentase kesiapan mereka hanya $71,6 \%$ saja, namun keseriusan mereka sudah sangat baik (85\%). Reaksi peserta terhadap penampilan widyaiswara dapat dikatakan baik dalam berbagai hal yang diberi penilaian yakni: penyajian materi, penguasaan materi, penggunaan metode dan bahasa serta usaha pemberian motivasi kepada peserta dan evaluasi reaksi peserta terhadap kesesuaian materi 
dengan tugas-tugas kantor dapat dikatagorikan efektif karena skor rata-rata persentase maksimum adalah $78,7 \%$.

Pada tahapan pembelajaran (learning), karena tidak dilaksanakan tes sebelum diklat (pretest) maka tidak tampak perbedaan pengetahuan yang diperoleh dari diklat. Sedangkan tes sesudah diklat (posttest) menunjukkan hasil yang amat baik dengan nilai rata-rata 87. Nilai tertinggi peserta adalah 93,15 dan terendah adalah 81,21. Penilaian ini adalah penilaian dari aspek sikap dan perilaku kepemimpinan sebesar $45 \%$, dan dari aspek akademik/penguasaan materi sebesar $55 \%$.

Kaitannya dengan keterpakaian materi diklat, mayoritas peserta mengatakan bahwa materi diklat relevan dengan tugas-tugas pejabat eselon III. Dan ini berdampak pada terjadinya peningkatan pengetahuan yang dirasakan peserta adalah dalam bidang kepemimpinan (leadership), pengetahuan tentang organisasi kerja, tata kelola dan pengetahuan tentang pemecahan masalah (problem solving). Ini semua tentu memberikan andil yang cukup besar pada pening-katan professionalisme pimpinan eselon III di Kementerian agama.

Tahapan perilaku (behavior) menunjukkan terjadinya peningkatan loyalitas terhadap pekerjaan/tugas di kantor dan adanya peningkatan kemampuan berkomunikasi, kepercayaan diri, keterbukaan terhadap saran dari staf dan kritikan dari atasan, kemampuan pengendalian emosi pada saat yang rumit, dan kemampuan team work yang meningkat, serta kesediaan untuk mentransfer pengetahuan kepada staf. Namun ada beberapa hal yang perlu dihatikan oleh alumni diklatpim III yakni dalam hal penerapan dan mempertahankan ilmu, pengendalian emosi dan kejelasaan dalam pemberian arahan kepada staf masih dalam katagori belum baik.

Pada tahap hasil/result kualitas kerja alumni menurut penilaian staf, atasan dan mereka sendiri, terjadi peningkatan yang cukup baik dan ketuntasan kerja juga dapat lebih efektif dengan waktu yang tidak melebihi batas waktu (timelimit) yang ditetapkan. Hal ini berdampak pada efisiensi kerja serta dapat mengurangi pembiayaan. Berdasarkan evaluasi terhadap hasil (result) dari diklatpim III dapat disimpulkan bahwa diklatpim telah dapat memberikan dampak atau hasil yang baik terhadap lingkungan kerja dan penampilan kerja (work performance) para alumni diklatpim eselon III angkatan ke XXIII tahun 2008. Namun ada satu bidang yang masih perlu perhatian yakni kemampuan dan frekuensi berkomunikasi dalam bahasa Inggris yang dituntut sebagai pimpinan eselon III.

\section{DAFTAR PUSTAKA}

Ayers, Jerry B. (2008). "Evaluating Workshops and Institutes." Tennessee Technological University Practical Assessment, Research \& Evaluation, Vol. 1 (8). http://pareonline.net/getvn.asp?v=1\&n=8. 
Birnbrauer, H. (1987). "Evaluation Techniques that Work". Training and Development Journal. Vol. 41 (7). pp. 53-55.

Brinkerhoff, Robert O., et al. (1986). Program Evaluation: A Practitioner's Guide for Trainers and Educators. Boston: Kluwer Nijhoff Publishing, 1986.

Fitzpatrick, J. L., James R. Sanders, dan Elaine R. Worthen. (2004). Program Evaluation: Alternative Approaches and Practical Guidelines. Library of Congress Cataloging in Publication Data.

Keputusan Kepala Lembaga Adminstrasi Negara Nomor 54/2001. (2001). Pedoman Penyelenggaraan Pendidikan Dan Pelatihan Kepemimpinan Tingkat III. Jakarta: Lembaga Adminstrasi Negara.

Kirkpatrick, Donald. (2006). Evaluating Training Programs. San Francisco: BerrettKoehler Publishers, Inc., 2006.

Tayibnapis, F. Yusuf. (2000). Evaluasi Program. Jakarta: Rineka Cipta.

Peraturan Pemerintah Nomor 101 Tahun 2000 tentang Pendidikan dan Pelatihan Jabatan Pegawai Negeri Sipil. http://http://www.lan.go.id/doc/001.pdf. 